\title{
Muslims and Citizens
}


This page intentionally left blank 


\title{
9
}

\section{Muslims and Citizens}

Islam, Politics, and the French Revolution

\author{
Ian Coller
}

Yalc

UNIVERSITY PRESS 
Published with assistance from the Annie Burr Lewis Fund.

Copyright (C) 2020 by Ian Coller.

All rights reserved.

This book may not be reproduced, in whole or in part, including illustrations, in any form (beyond that copying permitted by Sections 107 and I08 of the U.S. Copyright Law and except by reviewers for the public press), without written permission from the publishers.

Yale University Press books may be purchased in quantity for educational, business, or promotional use. For information, please e-mail sales.press@yale.edu (U.S. office) or sales@yaleup.co.uk (U.K. office).

Set in Fournier MT type by IDS Infotech, Ltd.

Printed in the United States of America.

Library of Congress Control Number: 2019939489

ISBN 978-0-300-24336-9 (hardcover : alk. paper)

A catalogue record for this book is available from the British Library.

This paper meets the requirements of ANSI/NISO Z39.48-1992 (Permanence of Paper).

I098765432I 